\title{
FGF Signaling Is Necessary for Neurogenesis in Young Mice and Sufficient to Reverse Its Decline in Old Mice
}

\author{
Wenfei Kang and Jean M. Hébert \\ Departments of Neuroscience and Genetics, Albert Einstein College of Medicine, Bronx, New York 10461
}

The mechanisms regulating hippocampal neurogenesis remain poorly understood. Particularly unclear is the extent to which age-related declines in hippocampal neurogenesis are due to an innate decrease in precursor cell performance or to changes in the environment of these cells. Several extracellular signaling factors that regulate hippocampal neurogenesis have been identified. However, the role of one important family, FGFs, remains uncertain. Although a body of literature suggests that FGFs can promote the proliferation of cultured adult hippocampal precursor cells, their requirement for adult hippocampal neurogenesis in vivo and the cell types within the neurogenic lineage that might depend on FGFs remain unclear. Here, specifically targeting adult neural precursor cells, we conditionally express an activated form of an FGF receptor or delete the FGF receptors that are expressed in these cells. We find that FGF receptors are required for neural stem-cell maintenance and that an activated receptor expressed in all precursors can increase the number of neurons produced. Moreover, in older mice, an activated FGF receptor can rescue the age-related decline in neurogenesis to a level found in young adults. These results suggest that the decrease in neurogenesis with age is not simply due to fewer stem cells, but also to declining signals in their niche. Thus, enhancing FGF signaling in precursors can be used to reverse age-related declines in hippocampal neurogenesis.

Key words: aging; dentate gyrus; FGF receptor; hippocampus; mouse; neurogenesis

Significance Statement

Hippocampal deficits can result from trauma, neurodegeneration, or aging and can lead to loss of memory and mood control. The addition of new neurons to the hippocampus facilitates memory formation, but how this process is regulated and how we might manipulate it to reverse hippocampal dysfunction remains unclear. The FGF signaling pathway has been hypothesized to be important, but its role in generating new neurons had been poorly defined. Our study indicates that FGF signaling maintains and expands subsets of neural precursor cells. Moreover, in older mice, increasing FGF signaling is sufficient to reverse the decline in neuron production to levels found in young adults, providing a potential means of reversing age-related hippocampal deficits.

\section{Introduction}

In the adult hippocampus, neurogenesis normally occurs in the dentate gyrus (DG) with roles in memory ogenesis, and pattern separation. Neuron 70:589-596 (Aimone et al., 2011; Eisch and Petrik, 2012). Quiescent stem cells within the subgranular zone (SGZ) of the DG produce proliferative progenitors, which generate neuroblasts that mature and integrate into existing networks. How this process is regulated, why it declines with age, and

\footnotetext{
Received April 15, 2015; revised June 10, 2015; accepted June 11, 2015.

Author contributions: W.K. designed research; W.K. performed research; W.K. contributed unpublished reagents/analytic tools; W.K. and J.M.H. analyzed data; W.K. and J.M.H. wrote the paper.

This work was supported by grants from the Brain Research Foundation, the Hirschl/Weill-Caulier Foundation, the NIH (MH070596, NS088943), and the Einstein Cancer Center (NIH P30CA013330). We thank Helen Belalcazar for excellent technical support and to laboratory members for edits to the paper.

The authors declare no competing financial interests.

Correspondence should be addressed to Dr Jean M. Hébert, 1300 Morris Park Avenue, Department of Neuroscience, Albert Einstein College of Medicine, Bronx, NY, 10464. E-mail: jean.hebert@einstein.yu.edu.

DOI:10.1523/JNEUROSCI.1469-15.2015

Copyright $\odot 2015$ the authors $\quad 0270-6474 / 15 / 3510217-07 \$ 15.00 / 0$
}

how we might manipulate precursor cells to reverse hippocampal dysfunction upon damage or aging remains largely unknown.

In the SGZ, a dozen extracellular signals regulate steps in the neurogenic process (Alvarez-Buylla and Lim, 2004; Suh et al., 2009; Faigle and Song, 2013). Changes in these signals may also contribute to age-related declines or responses to damage (Rolando and Taylor, 2014). However, an important family of secreted factors, whose function in the adult SGZ is poorly defined, is FGFs.

Studies examining FGF function in SGZ neurogenesis yielded mixed results. Increasing FGF2 protein by intraventricular infusions in middle-aged mice or old rats leads to increased DG neurogenesis (Jin et al., 2003; Rai et al., 2007), whereas transgenic overexpression of Fgf2 alone with strong promoters does not increase neurogenesis (Taupin et al., 2000; Zucchini et al., 2008). These discrepancies could be due to age, abnormally high concentrations of infused versus transgenically generated FGF2, and/or inflammation that accompanies cannula-mediated infusion. Studies showing an FGF2-dependent neurogenic response 
in the DG from ischemia or seizures are consistent with a requirement for damage and/or inflammation facilitating FGF2-mediated neurogenesis (Yoshimura et al., 2001).

In Fgf $2^{-1-}$ or Nestin-Cre; Fgfr $1^{f x / f x}$ mice, FGF signaling is reduced and DG neurogenesis decreases (Zhao et al., 2007; Werner et al., 2011). However, adult hippocampal neurogenesis could be altered indirectly by developmental forebrain defects in $\mathrm{Fg} 2^{-1-}$ and $F g f r 1^{f x / f x}$ mutants and systemic defects in $F g f 2^{-1-}$ mutants (Dono et al., 1998; Ortega et al., 1998; Vaccarino et al., 1999; Raballo et al., 2000; Korada et al., 2002; Ohkubo et al., 2004; Smith et al., 2006, 2014; Tole et al., 2006). Moreover, reduced DG neurogenesis in Fgf2 $2^{-I-}$ mice is not rescued by infusion of FGF2 or mimicked with neutralizing FGF2-antibodies (Werner et al., 2011). Noteworthy is that deletion of Fgfr 2 specifically in adult GFAP-expressing precursors results in an eventual decline after 4 months in DG neurogenesis (Stevens et al., 2012). Nevertheless, the function of FGFs in the adult DG remain largely unresolved.

Here, to circumvent indirect and compensatory effects, we ablated all three DG-expressed FGF receptors, Fgfr1, Fgfr2, and Fgfr3 specifically in SGZ precursors in young and older adult mice. We also expressed an activated ligand-independent FGF receptor specifically in SGZ precursors. With these approaches, we establish whether FGF signaling directly in precursor cells is necessary or sufficient in promoting hippocampal neurogenesis at different ages.

\section{Materials and Methods}

Mice and treatments with BrdU and tamoxifen. The CAG-flox-stop-floxFgfr3TDII, Fgfr $1^{\text {flox }}, \mathrm{Fgfr} 2^{\text {flox }}, \mathrm{Fgfr} 3^{\text {flox }}, \mathrm{Fgfr}^{-}$, and Nestin-CreER mice were described previously (Deng et al., 1996; Trokovic et al., 2003; Yu et al., 2003; Balordi and Fishell, 2007; Su et al., 2010; Kang et al., 2014). Two to 3-month-old mice (young adults) or 12- to 14-month-old mice (aging adults) were used at the start of each experiment. Approximately equal numbers of males and females were used in each experiment and they exhibited similar phenotypes. Tamoxifen, $20 \mathrm{mg} / \mathrm{ml}$ in corn oil, was administered intraperitoneally ( $5 \mathrm{mg} / 35 \mathrm{~g}$ body weight) every other day for a total of five doses. For labeling newly generated neurons, BrdU (100 $\mathrm{mg} / \mathrm{kg}$ body weight) was injected intraperitoneally twice daily for $5 \mathrm{~d}$ starting after the last tamoxifen treatment. Brains of young or aging adult mice were collected for analysis 3-4 weeks after the last dose of tamoxifen treatment. For examining the proliferation of precursor cells, BrdU (100 $\mathrm{mg} / \mathrm{kg}$ body weight) was injected $2 \mathrm{~h}$ before the mice were killed.

Immunofluorescence. Mice were perfused intracardially with $4 \%$ paraformaldehyde and postfixed overnight in $4 \%$ paraformaldehyde at $4^{\circ} \mathrm{C}$, cryoprotected in $20 \%$ sucrose, and embedded in OCT. Tissue was cryosectioned at $20 \mu \mathrm{m}$ and mounted on slides before incubation with primary antibodies overnight at $4^{\circ} \mathrm{C}$ and with AlexaFluor-568, AlexaFluor-488, or AlexaFluor633 secondary antibodies (Invitrogen, 1:400) for $1 \mathrm{~h}$ at room temperature. For NeuN, BrdU, and Nestin staining, before blocking in goat serum, sections were heated in $10 \mathrm{~mm}$ sodium citrate at $\mathrm{pH} 6.0$ in a microwave oven for antigen retrieval. For BrdU, sections were then incubated with $2 \mathrm{~N} \mathrm{HCl}$ for $30 \mathrm{~min}$ at room temperature for DNA denaturation. TUNEL staining was performed following the manufacturer's protocol (Roche). Sections for controls and mutants were matched along the $\mathrm{A}-\mathrm{P}$ axis for comparisons. The following primary antibodies were used: rabbit anti-Caspase3 (1:200, Cell Signaling Technology), mouse anti-NeuN (1:100, Millipore), rabbit antiGFAP (1:500, Dako Cytomation), mouse anti-Ki67 (1:100, BD PharMingen), rat anti-Nestin (1:100, BD PharMingen), rabbit anti-DCX (1:400, Cell Signaling Technology), guinea pig anti-DCX (1:2000, Millipore), rat anti$\operatorname{BrdU}(1: 100$, Accurate). Sections were analyzed by fluorescence microscopy (Zeiss AxioSkop2) or confocal microscopy (Zeiss LSM-510 MetaDuo V2).

Fluoro-Jade B staining. Slide-mounted sections were washed with PBS and immersed in $100 \%$ ethanol for $3 \mathrm{~min}$ followed by $1 \mathrm{~min}$ rinse in $70 \%$ ethanol and one in distilled water. Slides were then incubated in $0.06 \%$ potassium permanganate for $15 \mathrm{~min}$, rinsed in water, and transferred to a $0.001 \%$ Fluoro-Jade B solution in $0.1 \%$ acetic acid for $30 \mathrm{~min}$. After staining, the slides were rinsed in water, air-dried on a hot plate, cleared with xylene, and coverslipped with Permount.

Quantification and statistical analyses. Cells were counted along the length of the dorsal blade of the DG in positionally matched coronal sections from control and mutant mice. Statistical analyses were performed using Student's $t$ test. At least three sections from both hemispheres for each of three mice per genotype were used for cell counts. The numbers were averaged and compared between mutant and control littermates. Data are presented as mean \pm SEM.

\section{Results}

\section{FGF receptors are both necessary and sufficient for} hippocampal neurogenesis

To characterize the function of FGF signaling in adult hippocampal precursor cells, Nestin-CreER mice were used to target adult neural stem and progenitor cells to avoid indirect developmental or nonautonomous effects. For loss-of-function (LOF) experiments, we conditionally deleted all three FGF receptor genes that are expressed in neural precursors (Nestin-CreER;Fgfr $1^{f x / f x}$; $F g f r 2^{f x / f x} ; F g f r 3^{f x /-}$; hereafter LOF mutants). For gain-of-function (GOF) experiments, we conditionally expressed a constitutively activated Fgfr3 transgene (Nestin-CreER;CAG-fx-stop-fx$F g f r 3^{T D I I}$; hereafter Fgfr3-GOF mutants). Littermate controls either did not carry Nestin-CreER or did not receive tamoxifen and no significant difference in phenotype could be observed between these controls. Similarly, mutants carrying Nestin-CreER and only subsets of the six-floxed Fgfr alleles exhibited relatively normal phenotypes at 3-4 weeks after tamoxifen treatment, consistent with functional compensation between the three Fgfr genes.

In the SGZ, three weeks after the end of tamoxifen treatment, the number of cells labeled with DCX or PSA-NCAM (markers for immature neurons) were significantly reduced in LOF mutants and increased in Fgfr3-GOF mutants (Fig. 1 A, C,D; DCX: control, $86.5 \pm 10.6$; LOF, $33.6 \pm 4.7$; Fgfr3-GOF, $144.1 \pm 14.6$ cells/mm; $p<0.01$; PSA-NCAM: control, $39.8 \pm 3.1$; LOF, $22.9 \pm 2.7$; Fgfr3-GOF, $60.7 \pm 5.0$ cells $/ \mathrm{mm}, p<0.01$; mean \pm SEM). To assess the numbers of newly generated mature neurons, sections were colabeled with $\mathrm{NeuN}$, a neuronal marker, and BrdU (administered 3 weeks before collecting brains). Consistent with the observed changes in immature neurons, newly matured neurons were reduced $\sim 5$-fold in LOF mutants, whereas they increased $\sim 6$-fold in Fgfr3-GOF mutants (Fig. $1 \mathrm{~B}, E$; control: $2.56 \pm 0.31$; LOF: $0.51 \pm 0.18$; Fgfr3-GOF: $14.93 \pm 1.95$ cells/ $\mathrm{mm}, p<0.001$; mean \pm SEM). These data indicate that FGF receptors are both necessary and sufficient to generate neurons in the adult DG.

\section{FGF receptors are necessary for stem-cell maintenance and sufficient for progenitor cell proliferation}

To assess whether the neurogenic phenotypes observed in the LOF and Fgfr3-GOF mutants were due to changes in the numbers of stem cells, progenitor cells, or both, we examined coexpression of GFAP with Nestin, which together mark stem cells, and Nestin with DCX, which together mark progenitors. Although the number of stem cells remained unchanged in Fgfr3-GOF mutants compared with controls, a significant decrease was observed in LOF mutants 3 weeks post-tamoxifen (Fig. $2 A, B$; control: $27.4 \pm$ 1.8 vs LOF: $19.7 \pm 1.7$ cells/mm, $p<0.001$; Fgfr3-GOF: $28.0 \pm$ 1.5 ; mean \pm SEM), indicating that FGF signaling is necessary to maintain stem cells but not sufficient to expand them.

Not surprisingly, LOF mutants had fewer progenitors (control: $9.71 \pm 0.89$ vs LOF: $1.88 \pm 0.51$ cells $/ \mathrm{mm}, p<0.001$; mean \pm SEM) and fewer Nestin $(-) \operatorname{DCX}(+)$ immature neurons (control: $22.1 \pm 1.6$ vs LOF: $10.8 \pm 1.8$ cells $/ \mathrm{mm}, p<0.001$; 


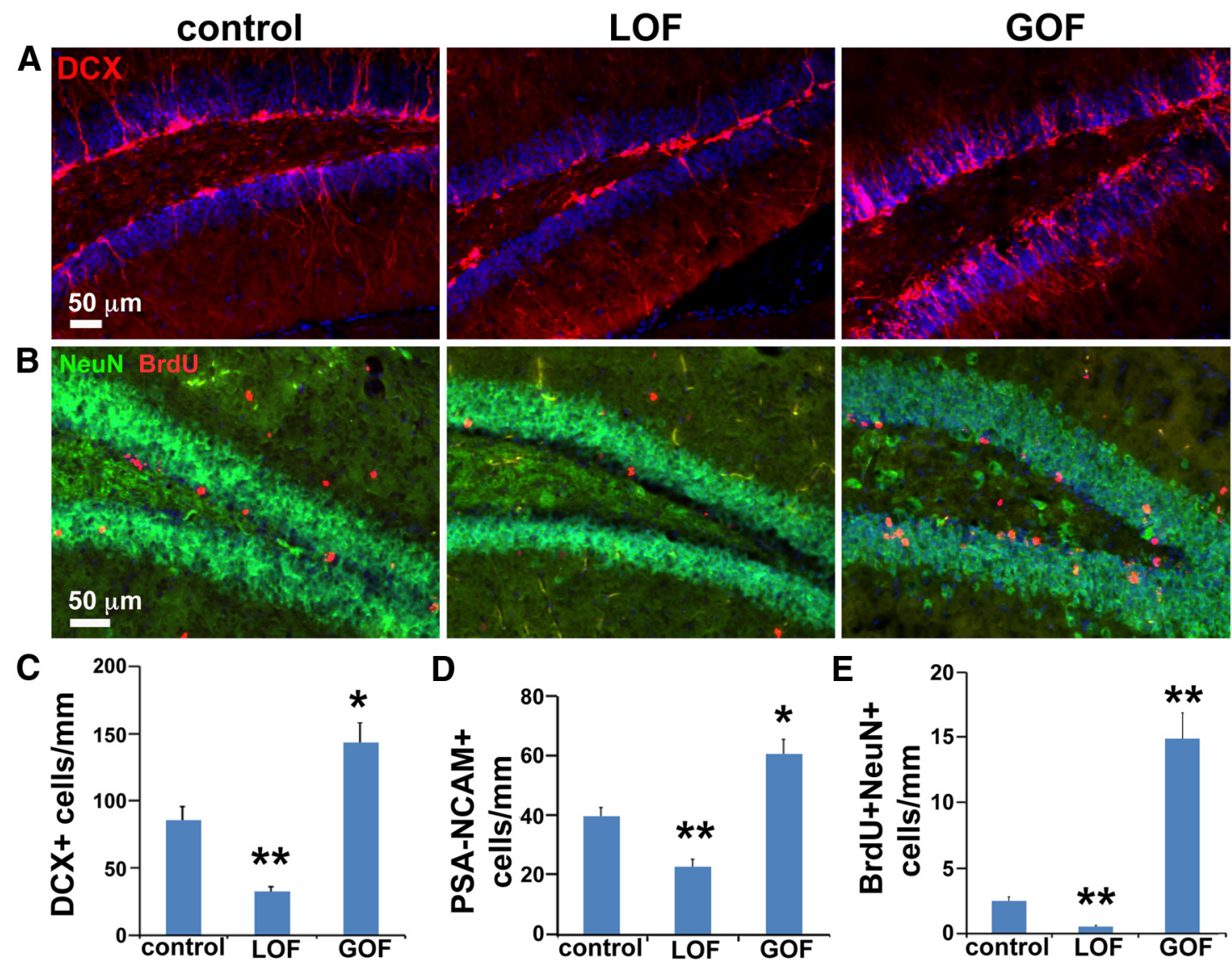

Figure 1. FGF signaling promotes adult hippocampal neurogenesis. $A$, Neuroblasts or immature neurons $(D C X+)$ and $(B)$ newly generated mature neurons $($ NeuN $+B r d U+)$ in the hippocampal DG are significantly decreased in the FGF receptor LOF mutant and increased in the Fgfr3-GOF mutant. DAPI counterstain (blue). C-E, Quantification of DCX+(C), PSA-NCAM+ (D), and $\mathrm{BrdU}+\mathrm{NeuN}+(\boldsymbol{E})$ cells; $^{*}$ and $^{* *}$ indicate significant differences with control, $p<0.01$ and $p<0.001$, respectively.

mean \pm SEM). In contrast, Fgfr3-GOF mutants displayed twice as many progenitors (control: $9.71 \pm 0.89$ vs Fgfr3-GOF: $23.2 \pm$ $3.47, p<0.001$; mean \pm SEM) and $70 \%$ more immature neurons (control: $22.1 \pm 1.6$ vs Fgfr3-GOF: $38.0 \pm 2.4$ cells/mm, $p<$ 0.001 ; Fig. $2 A, B)$. Results obtained using the proliferative marker Ki67 were consistent with a $\sim 50 \%$ decrease and $\sim 150 \%$ increase in proliferating progenitor cells in the LOF and Fgfr3-GOF mutants, respectively (Fig. $2 C$; control: $8.04 \pm 1.55$; LOF: $4.67 \pm$ 1.04; Fgfr3-GOF: $19.55 \pm 5.23$ cells/mm, $p<0.05$; mean \pm SEM). Because the number of stem cells in the Fgfr3-GOF mutants is unchanged, the increase in the number of progenitors suggests that FGF receptor activity is sufficient to directly promote their expansion. However, whether the decrease in progenitors in LOF mutants indicates a requirement for FGF receptors in directly promoting the proliferation of these cells remains unclear because a decrease in progenitors could simply reflect the observed decrease in stem cells (Fig. $2 A, B$ ). To address this issue, we examined the fraction of DCX + cells that were in S-phase using a short-term BrdU pulse. Whereas Fgfr3-GOF mutants showed an increase in the fraction of BrdU + DCX $+/ D C X+$ cells, no significant change was detected in LOF mutants (Fig. $2 D$; control: $2.41 \pm 0.73 \%$; LOF: $3.63 \pm 1.31 \%$; Fgfr3-GOF: $7.72 \pm$ $1.15 \% ; p>0.05$ for control vs LOF, $p<0.01$ for control vs Fgfr3-GOF; mean \pm SEM), suggesting that FGF signaling is not necessary for progenitor proliferation, but when enhanced it is sufficient to increase proliferation.
Increased FGF receptor activity reverses the age-related decline in hippocampal neurogenesis

Neurogenesis in the rodent hippocampus declines dramatically by 12 months of age with decreases in progenitor cell proliferation and survival of new neurons (Kuhn et al., 1996; Rao et al., 2006; Jessberger and Gage, 2008; Lugert et al., 2010; Encinas et al., 2011; Kuipers et al., 2015). The ability of FGF receptor activity to increase neurogenesis in young adults prompted us to test whether it could also reverse the compromised neurogenesis of older mice. Three weeks post-tamoxifen, 12- to 14-month-old control animals had few DCX + neuroblasts, equal to only $2.4 \%$ of that in the young 3- to 4-month-old control animals, with simpler dendritic branches (Fig. $3 A, B$ ). In 12- to 14-month-old LOF mutants, there was no statistically significant difference in the number of neuroblasts compared with age-matched littermate controls. However, in old Fgfr3-GOF mutants, the number of neuroblasts was approximately three times higher than in littermate controls (Fig. 3 A, B; control: $2.04 \pm 0.32$ cells/mm; LOF: $1.35 \pm 0.41$; Fgfr3-GOF: $6.34 \pm 0.73$; $p<0.001$; mean \pm SEM), and the morphology of the neuroblasts in Fgfr3-GOF mutants was more complex with larger dendritic trees and more branches compared with controls. As in young mice, the increase in the number of neuroblasts was due to an increase in the number of progenitors, rather than stem cells, which instead decreased perhaps due to their activation and conversion to a progenitor state (Fig. 3C; GFAP+Nestin + cells: control, $14.5 \pm 1.3$; LOF, $15.1 \pm$ 

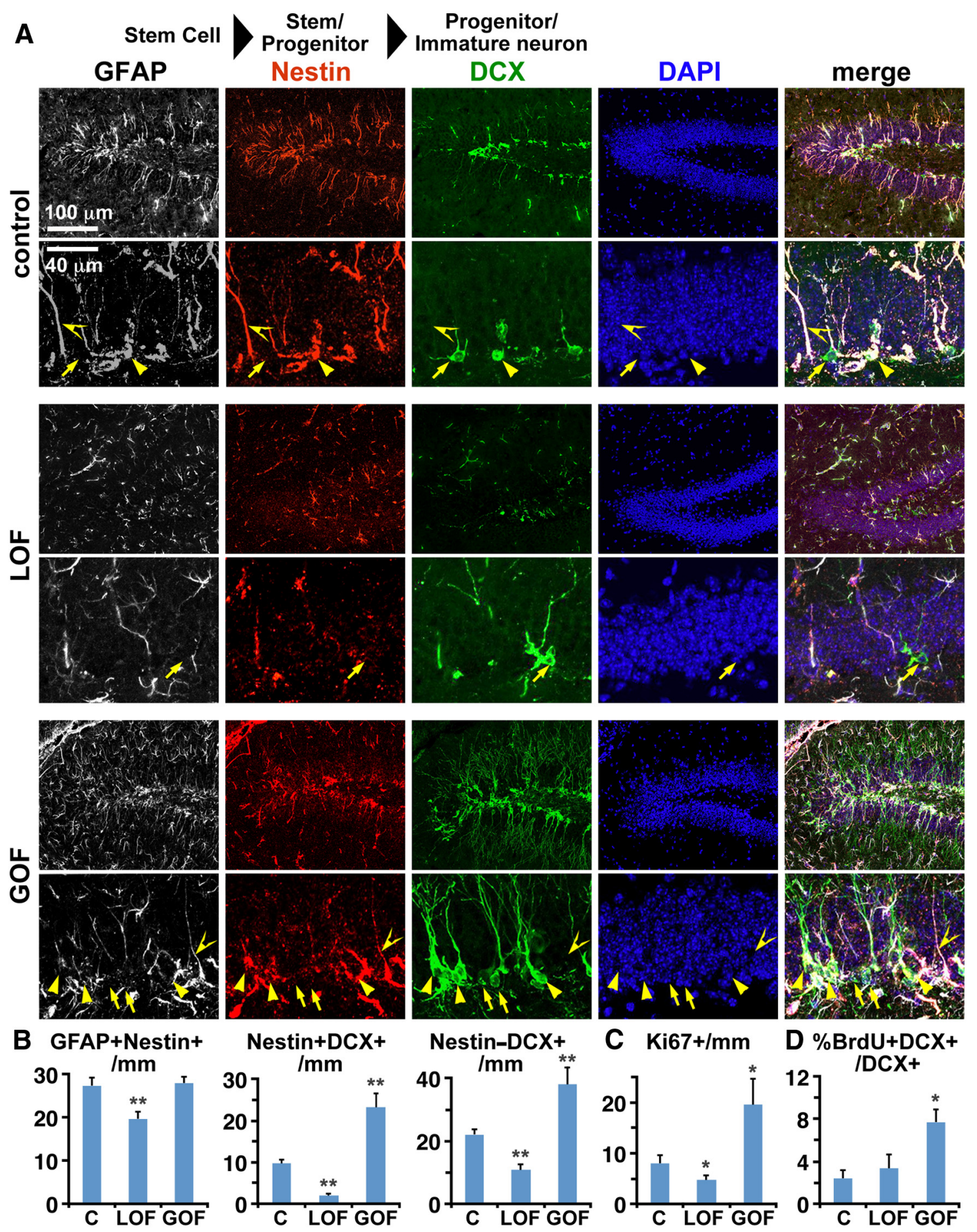

C $\mathrm{Ki} 67+/ \mathrm{mm}$
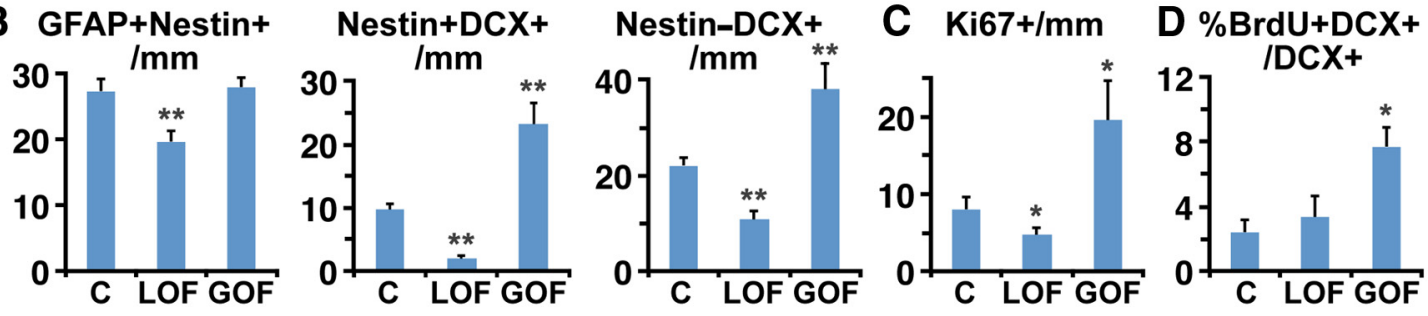

Figure 2. FGF signaling is necessary to maintain stem cell numbers and sufficient for expanding progenitor cells. $A$, Neural stem cells, progenitors, and immature neurons in the hippocampal DG were identified by combinations of markers. Neural stem cells (GFAP + Nestin +; carets) are decreased in LOF mutants but appear unchanged in Fgfr3-GOF mutants. Progenitor cells (Nestin + DCX +; arrowheads) and immature neurons (DCX+ only; arrows) are increased in Fgfr3-GOF mutants and decreased in LOF mutants. Lower (top) and higher (bottom) magnification views are presented. $\boldsymbol{B}-\boldsymbol{D}$, Quantification of GFAP + Nestin,+ Nestin $+D C X+$, and Nestin $(-) D C X+$ cells $(\boldsymbol{B})$, Ki67 + cells $(\boldsymbol{C})$ along with the percentage of $\mathrm{DCX}+$ cells that were BrdU + after a $2 \mathrm{~h}$ BrdU pulse (D); ${ }^{*}$ and ${ }^{* *}$ indicate significant differences with control, $p<0.05$ and $p<0.001$, respectively. Colabeling was quantified by confocal microscopy.

1.1; Fgfr3-GOF, $6.9 \pm 1.8$; Nestin +DCX + cells: control, $0.61 \pm$ 0.23 ; LOF, $1.12 \pm 0.29$; Fgfr3-GOF, $3.16 \pm 1.0$ ). In old control mice, the number of new mature neurons $(\mathrm{NeuN}+\mathrm{BrdU}+, 3$ weeks after BrdU treatment) was only $\sim 15 \%$ of that in young controls. Unlike in young mice, the older LOF mutants produced as many neurons as the older controls (control: $0.37 \pm 0.17$ vs LOF: $0.31 \pm 0.31$ cells $/ \mathrm{mm}, p>0.05$; mean \pm SEM), consistent with decreased FGF signaling underlying the normal age-related decline in hippocampal neurogenesis. In contrast, old Fgfr3-GOF mutants generated approximately five times more new neurons than old controls (control: $0.37 \pm 0.17$ vs Fgfr3-GOF: $1.84 \pm 0.35$ cells $/ \mathrm{mm}, p<0.001$; mean \pm SEM; Fig. $3 C$ ), reaching a level comparable to that in normal young mice (young control: $2.56 \pm$ 0.31 vs old Fgfr3-GOF: $1.84 \pm 0.35$ cells $/ \mathrm{mm}, p>0.05$; mean \pm 
A
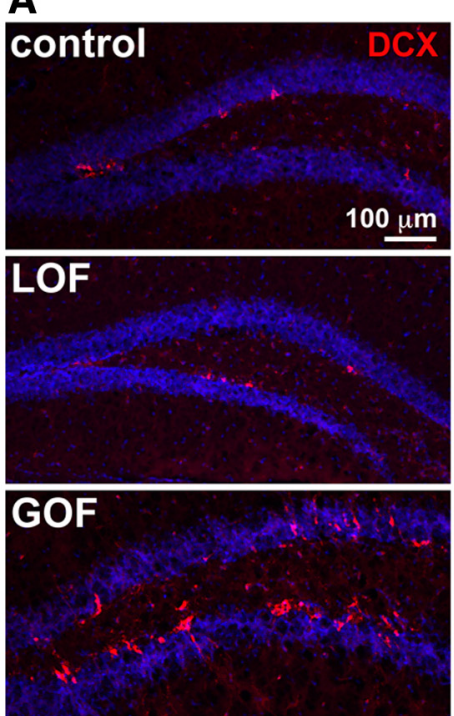

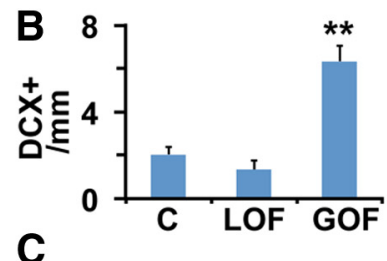

C

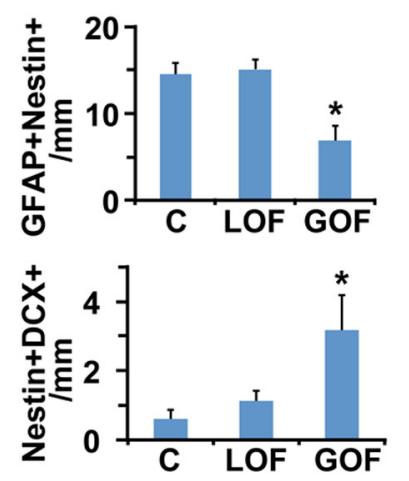

D

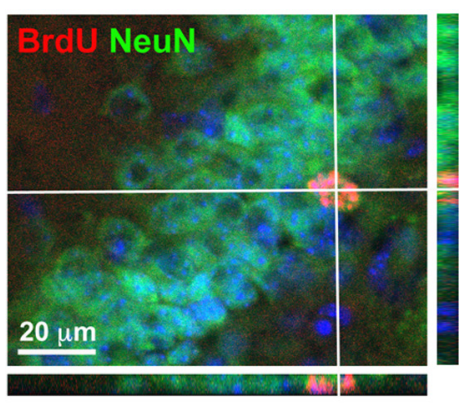

E

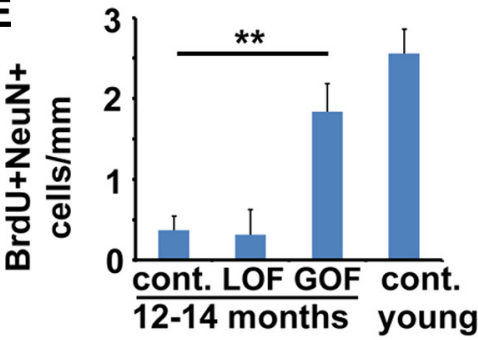

Figure 3. Increasing FGF receptor activity reverses the age-related decline in hippocampal neurogenesis. $\boldsymbol{A}, \mathrm{DCX}+$ immature neurons in the hippocampal DG significantly increase in 12 - to 14-month-old Fgfr3-GOF mutants compared with littermate controls. Right, Typical examples of dendritic arborizations, which are more complex in Fgfr3-GOF mutants. Quantification of DCX+ cells $(\boldsymbol{B})$ and GFAP + Nestin + and Nestin $+\mathrm{DCX}+$ progenitor cells $(\boldsymbol{C}){ }^{*}{ }^{*}$ and ${ }^{* *}$ indicate significant differences with control, $p<0.05$ and $p<0.001$, respectively. $\boldsymbol{D}$, Confocal image of a newly generated BrdU + NeuN + neuron in a 12-month-old Fgfr3-GOF mutant. DAPI counterstain (blue). $\boldsymbol{E}$, The number of new neurons increases in 12- to 14-month-old Fgfr3-G0F mutants to levels comparable with young controls (mean \pm SEM; ${ }^{* *} p<0.001$ ).

SEM), indicating that FGF signaling is sufficient to reverse the age-related decline in neuron production.

\section{Discussion}

Previous studies of FGFs in adult hippocampal neurogenesis yielded inconsistent results. Here, using conditional genetic approaches to decrease or increase FGF signaling in adult stem/ progenitor cells in vivo, we find that FGF signaling is required in stem cells to maintain their normal numbers but not sufficient to increase them, suggesting that stem cell numbers might be at a plateau in young adults. Conversely, in progenitor cells, FGF signaling is not required to maintain their numbers or promote their proliferation (with decreased progenitors in LOF mutants due simply to decreased stem cells), but is sufficient to enhance progenitor proliferation, leading to increased numbers of neuroblasts and neurons. The requirement for FGF receptors in maintaining stem but not progenitor cells in the adult hippocampus is reminiscent of their role in maintaining cortical radial glial stem cells but not progenitors during development (Kang et al., 2009).

In this study, we used a constitutively active form of Fgfr3 to increase FGF signaling. There is no conclusive evidence to date that would allow us to predict that the use of constitutively active forms of Fgfr1 and/or Fgfr2 would have yielded similar results. Nevertheless, previous studies support the notion that signaling through FGFR1, FGFR2, and FGFR3 is functionally similar. A transgenically expressed chimeric receptor composed of the extracellular and transmembrane domains of FGFR3 and the intracellular domain of FGFR1 behaves like FGFR3 in chondrocytes (Wang et al., 2001). In zebrafish, expression of constitutively active forms of FGFR1, FGFR2, and FGFR3 each result in similar phenotypes (Ota et al., 2009). Finally, when the three Fgfr genes, Fgfr 1, Fgfr2, and Fgfr3, are simultaneously deleted in developing mouse tissues, dramatically more severe phenotypes are obtained compared with single- or double-mutants (Saarimäki-Vire et al., 2007; Kang et al., 2009, 2014; Paek et al., 2009; this study), sug- gesting that the receptors likely compensate for each other by signaling through similar intracellular pathways.

In the adult DG, $\sim 50 \%$ of newly generated neurons die within a month after their birth (Dayer et al., 2003). FGF signaling is essential for cell survival in multiple developing tissues, including the embryonic telencephalon and mid-hindbrain junction (Sato et al., 2004; Zervas et al., 2005; Paek et al., 2009). Hence, we asked whether FGF signaling also plays a role in the survival of newly generated immature neurons in the adult hippocampus. However, TUNEL assays, anti-activated caspase 3 antibody stains, and Fluoro-Jade B staining did not reveal quantifiable cell death (Biebl et al., 2000; White and Barone, 2001; as also reported by others) regardless of genotype. Nevertheless, in older Fgfr3-GOF mutants, although the number of DCX + cells (neuroblasts and immature neurons) is significantly increased compared with littermate controls, it remains $\sim 10$-fold lower than young controls. Despite this, the older Fgfr3-GOF mutants have numbers of new mature NeuN + neurons comparable to young controls, suggesting that in addition to promoting proliferation, increasing FGF signaling in older mice may promote the survival of newborn neurons.

In fact, we show that increasing FGF receptor activity in neural precursor cells of older adults reverses the decline in neurogenesis, returning levels to those found in young adults. This finding, together with a previous study that reported increased hippocampal neurogenesis following intraventricular infusion of FGF2 to old rats (Jin et al., 2003), suggests first that FGFs act directly on hippocampal stem cells and second that the decrease in neurogenesis with age is not only due to a decreased ability of stem cells to generate new neurons or respond to FGF signals, but also a decrease in the availability of ligands in their environment. A scarcity of FGF ligands in the hippocampus with age could also explain why disrupting FGF receptors in older adults does not significantly reduce the already low levels of neurogenesis. Consistent with the idea that decreased FGF ligands with age results in 
decreased hippocampal neurogenesis, expression of FGF2 in the DG is reduced in old animals (Shetty et al., 2005). However, in addition to FGF2, there are 22 other FGFs, some of which may be expressed locally in the hippocampal stem-cell niche, and three of which, the circulating endocrine FGFs, may reach stem cells in the DG via their close association with the vasculature (Palmer et al., 2000). Therefore, the identity of the FGF ligand(s) that affect neurogenesis with age remains unclear.

The notion that stem cells in old mice can be activated to restore neurogenesis is also supported by previous evidence. The activity of neural precursor cells declines with age, yet their numbers do not necessarily decrease (Hattiangady and Shetty, 2008; Lugert et al., 2010). Furthermore, exercise and environmental enrichment in old mice can increase neurogenesis to more youthful levels (Kempermann et al., 2002; van Praag et al., 2005), and kainic acid-induced seizures can reactivate the proliferative state of neural precursor cells (Rao et al., 2008; Lugert et al., 2010). How exercise, environmental enrichment, or seizures activate precursors is unknown, but it is interesting to speculate that these factors act at least in part by stimulating FGF signaling.

Altogether, this study establishes FGF signaling as a critical regulator of adult hippocampal neurogenesis in vivo. Furthermore, the ability of increased FGF signaling to restore neurogenesis in aging animals makes it a potential target for the prevention or reversal of age-related deficits in hippocampal function.

\section{References}

Aimone JB, Deng W, Gage FH (2011) Resolving new memories: a critical look at the dentate gyrus, adult neurogenesis, and pattern separation. Neuron 70:589-596. CrossRef Medline

Alvarez-Buylla A, Lim DA (2004) For the long run: maintaining germinal niches in the adult brain. Neuron 41:683-686. CrossRef Medline

Balordi F, Fishell G (2007) Mosaic removal of hedgehog signaling in the adult SVZ reveals that the residual wild-type stem cells have a limited capacity for self-renewal. J Neurosci 27:14248-14259. CrossRef Medline

Biebl M, Cooper CM, Winkler J, Kuhn HG (2000) Analysis of neurogenesis and programmed cell death reveals a self-renewing capacity in the adult rat brain. Neurosci Lett 291:17-20. CrossRef Medline

Dayer AG, Ford AA, Cleaver KM, Yassaee M, Cameron HA (2003) Shortterm and long-term survival of new neurons in the rat dentate gyrus. J Comp Neurol 460:563-572. CrossRef Medline

Deng C, Wynshaw-Boris A, Zhou F, Kuo A, Leder P (1996) Fibroblast growth factor receptor 3 is a negative regulator of bone growth. Cell 84:911-921. CrossRef Medline

Dono R, Texido G, Dussel R, Ehmke H, Zeller R (1998) Impaired cerebral cortex development and blood pressure regulation in FGF-2-deficient mice. EMBO J 17:4213-4225. CrossRef Medline

Eisch AJ, Petrik D (2012) Depression and hippocampal neurogenesis: a road to remission? Science 338:72-75. CrossRef Medline

Encinas JM, Michurina TV, Peunova N, Park JH, Tordo J, Peterson DA, Fishell G, Koulakov A, Enikolopov G (2011) Division-coupled astrocytic differentiation and age-related depletion of neural stem cells in the adult hippocampus. Cell Stem Cell 8:566-579. CrossRef Medline

Faigle R, Song H (2013) Signaling mechanisms regulating adult neural stem cells and neurogenesis. Biochim Biophys Acta 1830:2435-2448. CrossRef Medline

Hattiangady B, Shetty AK (2008) Aging does not alter the number or phenotype of putative stem/progenitor cells in the neurogenic region of the hippocampus. Neurobiol Aging 29:129-147. CrossRef Medline

Jessberger S, Gage FH (2008) Stem-cell-associated structural and functional plasticity in the aging hippocampus. Psychol Aging 23:684-691. CrossRef Medline

Jin K, Sun Y, Xie L, Batteur S, Mao XO, Smelick C, Logvinova A, Greenberg DA (2003) Neurogenesis and aging: FGF-2 and HB-EGF restore neurogenesis in hippocampus and subventricular zone of aged mice. Aging Cell 2:175-183. CrossRef Medline

Kang W, Wong LC, Shi SH, Hébert JM (2009) The transition from radial glial to intermediate progenitor cell is inhibited by FGF signaling during corticogenesis. J Neurosci 29:14571-14580. CrossRef Medline
Kang W, Balordi F, Su N, Chen L, Fishell G, Hébert JM (2014) Astrocyte activation is suppressed in both normal and injured brain by FGF signaling. Proc Natl Acad Sci U S A 111:E2987-E2995. CrossRef Medline

Kempermann G, Gast D, Gage FH (2002) Neuroplasticity in old age: sustained fivefold induction of hippocampal neurogenesis by long-term environmental enrichment. Ann Neurol 52:135-143. CrossRef Medline

Korada S, Zheng W, Basilico C, Schwartz ML, Vaccarino FM (2002) Fibroblast growth factor 2 is necessary for the growth of glutamate projection neurons in the anterior neocortex. J Neurosci 22:863-875. Medline

Kuhn HG, Dickinson-Anson H, Gage FH (1996) Neurogenesis in the dentate gyrus of the adult rat: age-related decrease of neuronal progenitor proliferation. J Neurosci 16:2027-2033. Medline

Kuipers SD, Schroeder JE, Trentani A (2015) Changes in hippocampal neurogenesis throughout early development. Neurobiol Aging 36:365-379. CrossRef Medline

Lugert S, Basak O, Knuckles P, Haussler U, Fabel K, Götz M, Haas CA, Kempermann G, Taylor V, Giachino C (2010) Quiescent and active hippocampal neural stem cells with distinct morphologies respond selectively to physiological and pathological stimuli and aging. Cell Stem Cell 6:445-456. CrossRef Medline

Ohkubo Y, Uchida AO, Shin D, Partanen J, Vaccarino FM (2004) Fibroblast growth factor receptor 1 is required for the proliferation of hippocampal progenitor cells and for hippocampal growth in mouse. J Neurosci 24: 6057-6069. CrossRef Medline

Ortega S, Ittmann M, Tsang SH, Ehrlich M, Basilico C (1998) Neuronal defects and delayed wound healing in mice lacking fibroblast growth factor 2. Proc Natl Acad Sci U S A 95:5672-5677. CrossRef Medline

Ota S, Tonou-Fujimori N, Yamasu K (2009) The roles of the FGF signal in zebrafish embryos analyzed using constitutive activation and dominantnegative suppression of different FGF receptors. Mech Dev 126:1-17. CrossRef Medline

Paek H, Gutin G, Hébert JM (2009) FGF signaling is strictly required to maintain early telencephalic precursor cell survival. Development 136: 2457-2465. CrossRef Medline

Palmer TD, Willhoite AR, Gage FH (2000) Vascular niche for adult hippocampal neurogenesis. J Comp Neurol 425:479-494. CrossRef Medline

Raballo R, Rhee J, Lyn-Cook R, Leckman JF, Schwartz ML, Vaccarino FM (2000) Basic fibroblast growth factor (Fgf2) is necessary for cell proliferation and neurogenesis in the developing cerebral cortex. J Neurosci 20: 5012-5023. Medline

Rai KS, Hattiangady B, Shetty AK (2007) Enhanced production and dendritic growth of new dentate granule cells in the middle-aged hippocampus following intracerebroventricular FGF-2 infusions. Eur J Neurosci 26:1765-1779. CrossRef Medline

Rao MS, Hattiangady B, Shetty AK (2006) The window and mechanisms of major age-related decline in the production of new neurons within the dentate gyrus of the hippocampus. Aging Cell 5:545-558. CrossRef Medline

Rao MS, Hattiangady B, Shetty AK (2008) Status epilepticus during old age is not associated with enhanced hippocampal neurogenesis. Hippocampus 18:931-944. CrossRef Medline

Rolando C, Taylor V (2014) Neural stem cell of the hippocampus: development, physiology regulation, and dysfunction in disease. Curr Top Dev Biol 107:183-206. CrossRef Medline

Saarimäki-Vire J, Peltopuro P, Lahti L, Naserke T, Blak AA, Vogt Weisenhorn DM, Yu K, Ornitz DM, Wurst W, Partanen J (2007) Fibroblast growth factor receptors cooperate to regulate neural progenitor properties in the developing midbrain and hindbrain. J Neurosci 27:8581-8592. CrossRef Medline

Sato T, Joyner AL, Nakamura H (2004) How does FGF signaling from the isthmic organizer induce midbrain and cerebellum development? Dev Growth Differ 46:487-494. CrossRef Medline

Shetty AK, Hattiangady B, Shetty GA (2005) Stem/progenitor cell proliferation factors FGF-2, IGF-1, and VEGF exhibit early decline during the course of aging in the hippocampus: role of astrocytes. Glia 51:173-186. CrossRef Medline

Smith KM, Ohkubo Y, Maragnoli ME, Rasin MR, Schwartz ML, Sestan N, Vaccarino FM (2006) Midline radial glia translocation and corpus callosum formation require FGF signaling. Nat Neurosci 9:787-797. CrossRef Medline

Smith KM, Maragnoli ME, Phull PM, Tran KM, Choubey L, Vaccarino FM (2014) Fgfr1 inactivation in the mouse telencephalon results in impaired 
maturation of interneurons expressing parvalbumin. PLoS One 9:e103696. CrossRef Medline

Stevens HE, Jiang GY, Schwartz ML, Vaccarino FM (2012) Learning and memory depend on fibroblast growth factor receptor 2 functioning in hippocampus. Biol Psychiatry 71:1090-1098. CrossRef Medline

Su N, Xu X, Li C, He Q, Zhao L, Li C, Chen S, Luo F, Yi L, Du X, Huang H, Deng C, Chen L (2010) Generation of Fgfr3 conditional knockout mice. Int J Biol Sci 6:327-332. CrossRef Medline

Suh H, Deng W, Gage FH (2009) Signaling in adult neurogenesis. Annu Rev Cell Dev Biol 25:253-275. CrossRef Medline

Taupin P, Ray J, Fischer WH, Suhr ST, Hakansson K, Grubb A, Gage FH (2000) FGF-2-responsive neural stem cell proliferation requires CCg, a novel autocrine/paracrine cofactor. Neuron 28:385-397. CrossRef Medline

Tole S, Gutin G, Bhatnagar L, Remedios R, Hébert JM (2006) Development of midline cell types and commissural axon tracts requires Fgfrl in the cerebrum. Dev Biol 289:141-151. CrossRef Medline

Trokovic R, Trokovic N, Hernesniemi S, Pirvola U, Vogt Weisenhorn DM, Rossant J, McMahon AP, Wurst W, Partanen J (2003) FGFR1 is independently required in both developing mid- and hindbrain for sustained response to isthmic signals. EMBO J 22:1811-1823. CrossRef Medline

Vaccarino FM, Schwartz ML, Raballo R, Nilsen J, Rhee J, Zhou M, Doetschman T, Coffin JD, Wyland JJ, Hung YT (1999) Changes in cerebral cortex size are governed by fibroblast growth factor during embryogenesis. Nat Neurosci 2:848. CrossRef Medline

van Praag H, Shubert T, Zhao C, Gage FH (2005) Exercise enhances learning and hippocampal neurogenesis in aged mice. J Neurosci 25:86808685. CrossRef Medline

Wang Q, Green RP, Zhao G, Ornitz DM (2001) Differential regulation of endochondral bone growth and joint development by FGFR1 and FGFR3 tyrosine kinase domains. Development 128:3867-3876. Medline

Werner S, Unsicker K, von Bohlen und Halbach O (2011) Fibroblast growth factor-2 deficiency causes defects in adult hippocampal neurogenesis, which are not rescued by exogenous fibroblast growth factor-2. J Neurosci Res 89:1605-1617. CrossRef Medline

White LD, Barone S Jr (2001) Qualitative and quantitative estimates of apoptosis from birth to senescence in the rat brain. Cell Death Differ 8:345356. CrossRef

Yoshimura S, Takagi Y, Harada J, Teramoto T, Thomas SS, Waeber C, Bakowska JC, Breakefield XO, Moskowitz MA (2001) FGF-2 regulation of neurogenesis in adult hippocampus after brain injury. Proc Natl Acad Sci U S A 98:5874-5879. CrossRef Medline

Yu K, Xu J, Liu Z, Sosic D, Shao J, Olson EN, Towler DA, Ornitz DM (2003) Conditional inactivation of FGF receptor 2 reveals an essential role for FGF signaling in the regulation of osteoblast function and bone growth. Development 130:3063-3074. CrossRef Medline

Zervas M, Blaess S, Joyner AL (2005) Classical embryological studies and modern genetic analysis of midbrain and cerebellum development. Curr Top Dev Biol 69:101-138. CrossRef Medline

Zhao M, Li D, Shimazu K, Zhou YX, Lu B, Deng CX (2007) Fibroblast growth factor receptor- 1 is required for long-term potentiation, memory consolidation, and neurogenesis. Biol Psychiat 62:381-390. CrossRef Medline

Zucchini S, Buzzi A, Barbieri M, Rodi D, Paradiso B, Binaschi A, Coffin JD, Marzola A, Cifelli P, Belluzzi O, Simonato M (2008) Fgf-2 overexpression increases excitability and seizure susceptibility but decreases seizureinduced cell loss. J Neurosci 28:13112-13124. CrossRef Medline 